\title{
Artifact Repatriation and Collection Documentation
}

\section{Dan E. McGregor \\ Unknown}

Follow this and additional works at: https://scholarworks.sfasu.edu/ita

Part of the American Material Culture Commons, Archaeological Anthropology Commons, Environmental Studies Commons, Other American Studies Commons, Other Arts and Humanities Commons, Other History of Art, Architecture, and Archaeology Commons, and the United States History Commons

Tell us how this article helped you.

This Article is brought to you for free and open access by the Center for Regional Heritage Research at SFA ScholarWorks. It has been accepted for inclusion in Index of Texas Archaeology: Open Access Gray Literature from the Lone Star State by an authorized editor of SFA ScholarWorks. For more information, please contact cdsscholarworks@sfasu.edu. 


\section{Artifact Repatriation and Collection Documentation}

Creative Commons License

(c) (i) (8)

This work is licensed under a Creative Commons Attribution-NonCommercial 4.0 International License 


\section{Artifact Repatriation and Collection Documentation}

\section{Dan E. McGregor}

The Native American Graves Protection and Repatriation Act (NAGPRA) became law in November 1990, giving Native Americans control over the disposition of human remains and certain artifacts with which they have "cultural affiliation". For East Texas, most Native American burials are unquestionably affiliated with the Caddo Tribe of Oklahoma. Implementation of NAGPRA will affect the archaeological data base for East Texas. Repatriation of human remains and associated artifacts to the Caddo Tribe will be required of most curation facilities with collections from this region. Under NAGPRA, future excavation and analysis of human remains and associated artifacts will become increasingly difficult for Federally-sponsored projects.

There are two basic parts to NAGPRA. The first deals with existing collections of human remains and associated artifacts. This affects all museums, universities, and curation facilities receiving Federal funds after November 1990; this includes just about every facility with East Texas collections, whether Federal, State, or private. Under NAGPRA, inventories of human remains and associated artifacts (funerary objects) are to be completed by November 1995, followed by their repatriation (National Park Service 1993). These remains and artifacts will be turned over to the Caddo Tribe upon their request.

The second part of NAGPRA involves new projects on Federal or Tribal lands. Prior to any excavation likely to encounter human burials, Federal agency coordination and agreement with the affiliated tribe is required. We will need agreement about the "treatment" and "disposition" of human remains and associated artifacts. "Treatment" includes the question of excavation itself, as well as the kinds of analyses that may be conducted of excavated materials. "Disposition" refers to repatriation and reburial of these remains. The Caddo Tribe has made it clear that they prefer that Native American burials be preserved in place and excavated only if disturbance by project construction is unavoidable. As a result, future excavation and analysis of human remains and associated artifacts is increasingly unlikely for Federally-sponsored projects in East Texas on Federal or Tribal lands.

NAGPRA can be viewed as a threat to an important part of Caddoan archaeology's data base. But it also presents a challenge we need to address. Archaeologists working in East Texas must: (1) work with the Caddo Tribe of Oklahoma to insure that repatriated collections remain intact and accessible to researchers; (2) develop standards of documentation for both human remains and associated artifacts that are subject to 
repatriation; and (3) identify and document well-provenienced burial assemblages in the possession of private individuals.

\section{References}

National Park Service

1993 Summaries, Inventories, and Notification under the Native American Graves Protection and Repatriation Act of 1990. United States Department of the Interior, National Park Service, Washington, D.C. 